\title{
Practicality of Teaching Materials Developed by Using Problem Based Learning Based on PAKEM Model on Fraction Material in Elementary School
}

\author{
Refnywidialistuti * \\ Mathematics Department, Teacher Training and Education Faculty, Universitas Ekasakti, Padang, Indonesia \\ *Corresponding author. Email: refnywidia@gmail.com
}

\begin{abstract}
The fraction material studied in Elementary School is closely related to the daily life of students. The problem that exists in learning fractions is that students still memorize concepts and it is still difficult to apply concepts to problems that students encounter in their daily environment. The aim of this study is to determine the practicality of teaching materials, namely student books using PAKEM-oriented Problem Based Learning. The type of research is Research and Development (R\&D) using the Plomp model through 3 phases, namely the preliminary research, the development or prototyping phase, and the assessment phase. This research is limited to the practicality of using teaching materials from students and teachers. The results obtained indicate that in terms of teachers, the results are very high, in terms of students, high results are obtained. This means that the teaching materials used are practically used by students and teachers at the school.
\end{abstract}

Keywords: Fractions, PAKEM, Practicality, Problem Based Learning, Research and development

\section{INTRODUCTION}

Mathematics is a subject that plays an important role in the world of education. Mathematics learning is a subject that children learn from Elementary School to Higher Education levels. However, this subject is still one that students do not like because it still considers this subject to be boring and difficult. As the result, students get low learning outcomes.

Mathematics learning at elementary school, especially SDN 03 Muaro, Sijunjung District, has already referred to the 2013 curriculum. This means that teachers are required to become facilitators for students. Teachers must be able to make learning innovations so that students are active and creative. Several problems were found in schools, including the student books used which are made by the government. The books do not pay attention to the character of the students at the school. So that students still consider mathematics to be a difficult subject, because the existing books are still described not in accordance with what they feel in their environment. Therefore, learning really needs new teaching materials that are suitable to their characteristics and their daily environment.

According to Nieveen, quoted by Rochmad (2012) [1] states that measuring the level of practicality is seen from whether the teacher (and other experts) consider that the material is easy to understand and can be used by teachers and students. Therefore, the practicality of this student book was tested in a limited number, with a questionnaire sheet instrument in the form of teacher responses and student responses.

In developing this Student Book, it is necessary to apply a model. In this case, a model that suits student needs is used, namely Problem Based Learning. This model is characterized by the use of real-life problems as something students must learn to train and improve critical thinking and problem solving skills [2]. So that it matches the problems that occur in that class. To further enhance active, creative, and fun learning, the teaching materials in the form of Student Books are PAKEM (Pembelajaran Aktif, Kreatif, Efektif, dan Menyenangkan) model oriented.

The material taken by the researcher is fractions which is one of the main subjects in mathematics learning in elementary schools. Fractions are included in the material that is closely related to the daily life of students, where students are always dealing with fractions both at school and at home. For example, when at school students are asked to form group members by the teacher, this is a 
small part of the application of fractions in the school environment.

Based on the description above, this study explores how to develop student books in mathematics learning, especially fractions material. Then, the purpose of this research is to determine the practicality of the student book developed by using PAKEM-oriented Problem Based Learning on fractions material in grade fifth at SDN 03 Muaro, Sijunjung District.

\section{RESEARCH METHOD}

The development model used consists of three phases, namely the preliminary research, the development or prototyping phase, and the assessment phase [3]. The detailed Plomp development procedure includes the following steps:

a. The preliminary research phase, at this phase includes problem analysis, curriculum analysis, concept analysis, and student analysis.

b. The development phase includes designing prototype I, namely designing student books using the PAKEM-oriented PBL model, followed by prototype II by conducting self-evaluations using a checklist. Furthermore, prototype III, and prototype IV in this section of student books that have been validated. At this phase, 6 students in grade fifth Elementary School with high, medium and low abilities are given to do a small group / micro evaluation. The revision results in the small group evaluation phase resulted in a prototype IV and will be continued in the assessment phase by conducting a large group trial (field test).

c. Assessment phase. At this phase, trials were carried out on grade fifth elementary school students which aimed to see the practicality of student books. The practicality results were obtained from the practicality instruments of student books that were filled in by the teacher and students after learning to use the book.

The trial participants at this assessment phase were teachers and students of class VB SDN 03 Muaro which were appointed as the experimental class totaling 20 people. The research instrument used was a student book practicality questionnaire using PAKEM-oriented Problem Based Learning. This questionnaire is used to determine teacher responses and student responses to student books used during the learning process. Practicality considerations include aspects of ease of use, efficiency of learning time, attractiveness and benefits

The practicality sheet assessment was obtained from teacher response questionnaires and student response questionnaires which were analyzed using the Kappa Cohen formula. To determine the Kappa moment, the following formula is used moment kappa $(k)=\frac{P o-P e}{1-P e}$

Where: $P o=$ is the proportion that is realized, calculated by:

$$
\begin{gathered}
P_{0}=\frac{\text { scores given by validator }}{\text { maximum score }} \\
P e=\text { is the unrealized proportion, calculated by: } \\
P_{e}=\frac{\text { maximum score-scores given by validator }}{\text { mnrimum sonre }}
\end{gathered}
$$

The Kappa moment $(\mathrm{k})$ ranges from 0 to 1 with interpretations according to Boslaugh \& Watters (2008: 12) [4] presented in Table 1

Table 1. Interpretation of Kappa Moment Value (k)

\begin{tabular}{cc}
\hline Interval & Value \\
\hline $0.81-1.00$ & Very High \\
$0.61-0.80$ & High \\
$0.41-0.60$ & Fair \\
$0.21-0.40$ & Low \\
$0.01-0.20$ & Very Low \\
$\leq 0.00$ & Not Valid \\
\hline
\end{tabular}

\section{FINDINGS AND DISCUSSION}

An individual evaluation (one to one evaluation) was conducted on three students of class VB SDN 03 Muaro with high, medium and low abilities. Activities carried out at this phase are providing teaching materials in the form of student books to students and asking them to read to see the readability of the teaching materials. The aspects that are considered in this individual evaluation (one to one evaluation) are clarity, appeal, and obvious errors. After students have finished reading the teaching materials, informal interviews are conducted to find out their responses and opinions about the teaching materials developed.

Based on the results of informal interviews with students, it was found that the presentation of material, language and learning steps in teaching materials in the form of student books were presented clearly and easily understood by students. In terms of appeal, students expressed interest in and liked the appearance, images and colors used in these materials. Students also stated that they did not find writing errors and punctuation marks (obvious errors). Furthermore, the next phase is carried out, namely prototype IV.

Prototype IV was generated after conducting a small group evaluation activity. This small group evaluation was carried out on 6 grade fifth students of SDN 03 Muaro with high, medium and low abilities. The purpose of the small group evaluation is to test the practicality of teaching materials, namely the developed student books. This activity is carried out in 1 meeting by carrying out the learning process using the teaching materials developed. Each student is given student books as 
materials in the learning process. Firstly, an explanation is given to how and the steps for learning to use teaching materials. Then the researcher divided the students into small groups ( 2 people) for discussion. Initially students felt a little difficult to follow the learning steps in the teaching material to find concepts. This happens because students are accustomed to receiving concepts directly from the teacher in the learning process. However, after being given direction and assistance, students began to understand how to learn by using teaching materials to find concepts by themselves.

After the learning activity is complete, students are asked to fill out a questionnaire related to the practicality of using teaching materials in the learning process. The aspects assessed include ease of use, efficiency of learning time, benefits and attractiveness of teaching materials to student interests. The results of the practicality questionnaire analysis of teaching materials in small group evaluations can be seen in Table 2 .

Table 2 Practical Level of Teaching Materials, namely student books based on Student Responses (Small Group)

\begin{tabular}{|c|c|c|c|c|c|c|c|c|}
\hline Student & Score & $\begin{array}{l}\text { MAX } \\
\text { score }\end{array}$ & $\mathbf{P}$ & Pe & P-Pe & 1-Pe & $\mathbf{K}$ & $\begin{array}{c}\text { Practicality } \\
\text { value }\end{array}$ \\
\hline 1 & 27 & 32 & 0,84 & 0,16 & 0,69 & 0,84 & 0,81 & Very High \\
\hline 2 & 30 & 32 & 0,94 & 0,06 & 0,88 & 0,94 & 0,93 & Very High \\
\hline 3 & 28 & 32 & 0,88 & 0,13 & 0,75 & 0,88 & 0,86 & Very High \\
\hline 4 & 29 & 32 & 0,91 & 0,09 & 0,81 & 0,91 & 0,90 & Very High \\
\hline 5 & 26 & 32 & 0,81 & 0,19 & 0,63 & 0,81 & 0,77 & High \\
\hline 6 & 29 & 32 & 0,91 & 0,09 & 0,81 & 0,91 & 0,90 & Very High \\
\hline \multicolumn{7}{|c|}{ Practicality } & 0,86 & Very High \\
\hline
\end{tabular}

Based on Table 2, the practical value of teaching materials, namely student books from small group evaluation activities as a whole is 0.88 with a very high level of practicality.

Furthermore, a large group trial was carried out (field test) to see the effectiveness and practicality of the teaching materials being developed. Large group trials were carried out in the same school, namely SDN 03 Muaro, Sijunjung District, but using 2 classes, namely the VA and VB classes (control class and experimental class). The experimental class learned using teaching materials, namely developed student books, while the control class learned using textbooks from school. Practicality data were obtained through a practicality questionnaire given to teachers and students of the experimental class regarding the learning process using these teaching materials.

\subsection{Results of Practicality Questionnaire Analysis Based on Student Responses}

Practicality questionnaires were given to 20 students in the experimental class. The aspects that are assessed to determine the practicality of teaching materials include ease of use, efficiency of learning time, benefits and attractiveness of teaching materials to student interests. The summary of the results of the practicality questionnaire analysis based on student responses during the field test can be seen in Table 3 .
Table 3.The Level of Practicality of Teaching Materials based on Student Responses (Field Test)

\begin{tabular}{clcl}
\hline Items & Aspects & $\begin{array}{c}\text { Kappa } \\
\text { Moment }\end{array}$ & $\begin{array}{c}\text { Practicality } \\
\text { Value }\end{array}$ \\
\hline $1-5$ & Ease of use & 0,80 & High \\
$6-7$ & $\begin{array}{l}\text { Efficiency of } \\
\text { learning time }\end{array}$ & 0,75 & High \\
& $\begin{array}{l}\text { Benefits and } \\
8-10\end{array}$ & 0,74 & High \\
\hline \multicolumn{2}{l}{ Overall Practiveness } & & High \\
\hline
\end{tabular}

Based on Table 3, it can be seen that the average practical value of teaching materials, namely student books, based on the responses of class students from the aspects of ease of use, efficiency of learning time, benefits and attractiveness of teaching materials on student interest shows the kappa moment value of 0.77 with a high level of practicality. Thus, the teaching material is practically used as teaching material for learning mathematics in Elementary School grade fifth on fractions material.

\subsection{Results of Practicality Questionnaire Analysis Based on Teacher Responses}

Practicality questionnaires were also given to teachers who assisted researchers in carrying out learning activities using teaching materials, namely developed student books. The aspects assessed include ease of use, efficiency of 
learning time, benefits and attractiveness of teaching materials to student interests according to the teacher's opinion. Before being given to the teacher, this practicality questionnaire was validated by experts. Based on the results of the validation, this practicality questionnaire was declared valid as an instrument to collect data about the practicality of teaching materials. A practicality questionnaire based on the teacher's response was given to a grade fifth teacher at SDN 03 Muaro. The results of the practicality questionnaire analysis by the teacher can be seen in Table 4.

Table 4. Practical level of teaching materials, namely student books based on teacher responses

\begin{tabular}{clcc}
\hline Items & Aspects & $\begin{array}{c}\text { Kappa } \\
\text { Moment }\end{array}$ & $\begin{array}{c}\text { Practicality } \\
\text { Value }\end{array}$ \\
\hline $1-5$ & $\begin{array}{l}\text { Ease of use } \\
\text { Efficiency of } \\
\text { learning time } \\
\text { Benefits and } \\
7-10\end{array}$ & 0,86 & Very High \\
attractiveness & 0,75 & Hery High \\
\hline Overall Practicality & $\mathbf{0 . 8 7}$ & Very High \\
\hline
\end{tabular}

Table 4 shows that the teaching materials, namely the developed student books, have a very high level of practicality. This means that the teaching material is practically used in the teaching process by the teacher. Large group trials (field tests) aim to determine the level of practicality and effectiveness of teaching materials. The effectiveness or not of this teaching material can be seen from the percentage of students 'answers in the teaching materials, the effect of the use of teaching materials on student learning outcomes in the control and experimental classes, as well as tests of students' critical thinking skills. The practicality of teaching materials, namely student books, is related to the use of teaching materials, namely student books that are developed in the learning process. Products are categorized as practical if teachers or students (representatives of target user groups) can easily use the product as expected [3]. Practicality shows the level of ease of use and implementation of learning using the resulting product. Teaching materials are categorized as practical if they can be used to carry out learning logically and continuously, without many problems. Practicality considerations can be seen from the aspects of ease of use, efficiency of learning time, and attractiveness of teaching materials to student interests [5]. The level of practicality of the product can be seen by considering whether the product is easy to understand and can be used by teachers and students in normal conditions [6].

Learning using colored and pictorial teaching materials makes students interested in teaching materials so as to increase motivation in learning [7]. The use of teaching materials, namely student books that are colored and illustrated, makes students more excited and motivated to learn. Learning using teaching materials can stimulate students' intrinsic motivation to learn mathematics. The intrinsic motivation of students who learn mathematics using teaching materials, namely student books, is significantly higher than students who learn without teaching materials, namely student books [8].

In Problem Based Learning, the learning center is the student, while the teacher acts as a facilitator who facilitates students to actively solve problems and build their knowledge in pairs or groups [2]. The use of teaching materials, namely student books developed in the learning process, supports the role of the teacher as a facilitator because students must be active to find concepts about the material being studied by following the steps of the Problem Based Learning model contained in the teaching materials. The discovery process trains students to actively learn to find problems, formulate hypotheses, plan experiments, analyze data and make conclusions [9].

\section{CONCLUSION}

Based on the results and discussion, it can be concluded that the student books using Problem Based Learning PAKEM (Pembelajaran Aktif, Kreatif, Efektif, dan Menyenangkan) oriented on Fractions Material in grade fifth SD are categorized as very practical, it proved by the value very high with kappa moment value of 0.86 . From the results of interviews with students and teachers, information was also obtained that the teaching materials used could help students and teachers both in terms of time efficiency and ease of use. This student book teaching material is expected to be a guide for teachers. Testing of this learning device is still very limited, namely 20 students with one class only. It is hoped that the next researchers can conduct similar research with trials in various schools with various characteristics.

\section{ACKNOWLEDGMENT}

The researchers would like to thank:

Kemenristekdikti which has funded this research through novice lecturer with Nomor: 004/LPPM-UNES/ KONTRAK-PENELITIAN/2020r.

\section{REFERENCES}

[1] R. Rochmad, Desain model pengembangan perangkat pembelajaran matematika. Kreano, Jurnal Matematika Kreatif-Inovatif, 3(1) (2012) 59-72. DOI: https://doi.org/10.15294/kreano.v3i1.2613

[2] M. Hosnan, Pendekatan saintifik dan kontekstual dalam pembelajaran abad 21: Kunci sukses implementasi kurikulum 2013. 2014.

[3] T. Plomp, Educational design research: An introduction. Educational design research, (2013) 1150 . 
[4] B. Sarah, A. W. Paul, Statistics in a Nutshell, a Desktop Quick Reference. 2008.

[5] H. M. Sukardi, Evaluasi pendidikan prinsip dan operasionalnya. Jakarta: Bumi Aksara. 2008

[6] J. van den Akker, R. M. Branch, K. Gustafson, N. Nieveen, T. Plomp, Design approaches and tools in education and training. Springer Science \& Business Media. 2012.

[7] B. Ellizar, Andromeda. Pengaruh Motivasi dan Pembelajaran Kimia Menggunakan Modul dan Tanpa Modul terhadap Hasil Belajar Kimia di RSMABI. Prosiding Semirata FMIPA Universitas Lampung, (2013) 117-124.

[8] K. Vaino, J. Holbrook, M. Rannikmäe, Stimulating students' intrinsic motivation for learning chemistry through the use of context-based learning modules. Chemistry Education Research and Practice, 13(4) 410-419. DOI: $10.1039 / \mathrm{C} 2 \mathrm{RP} 20045 \mathrm{G}$

[9] A. Hofstein, O. Navon, M. Kipnis, R. MamlokNaaman, Developing students' ability to ask more and better questions resulting from inquiry-type chemistry laboratories. Journal of research in science teaching, 42(7) (2005) 791-806. DOI: https://doi.org/10.1002/tea.20072 